ex Instituto Archaeologico Universitatis de Rolando Eötvös nominatae

C

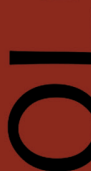

ப

$\varangle$

工

$\cup$

ه

$<$

in

ㄴ
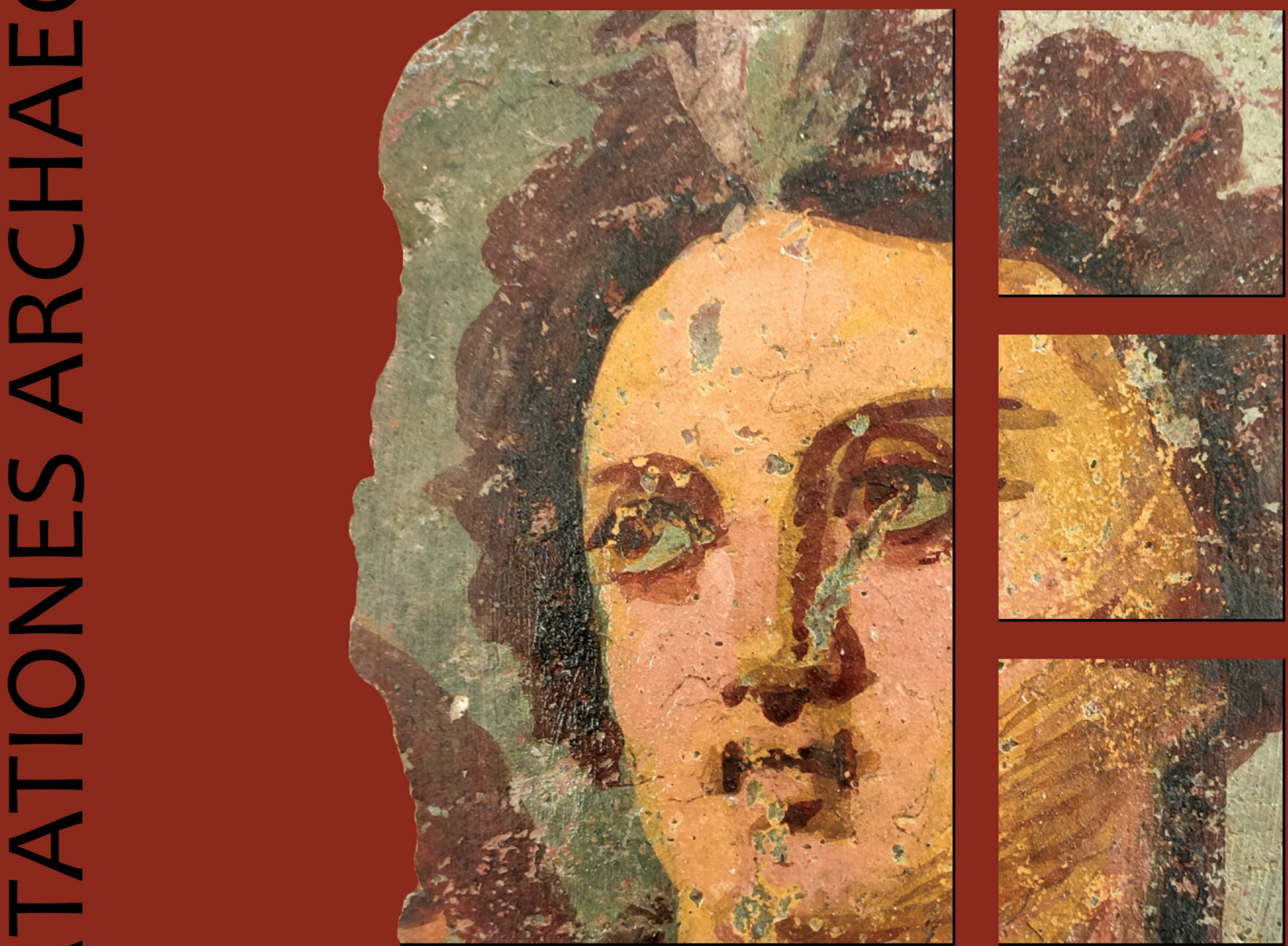

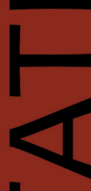

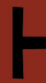

ח

Ш

un

n

0
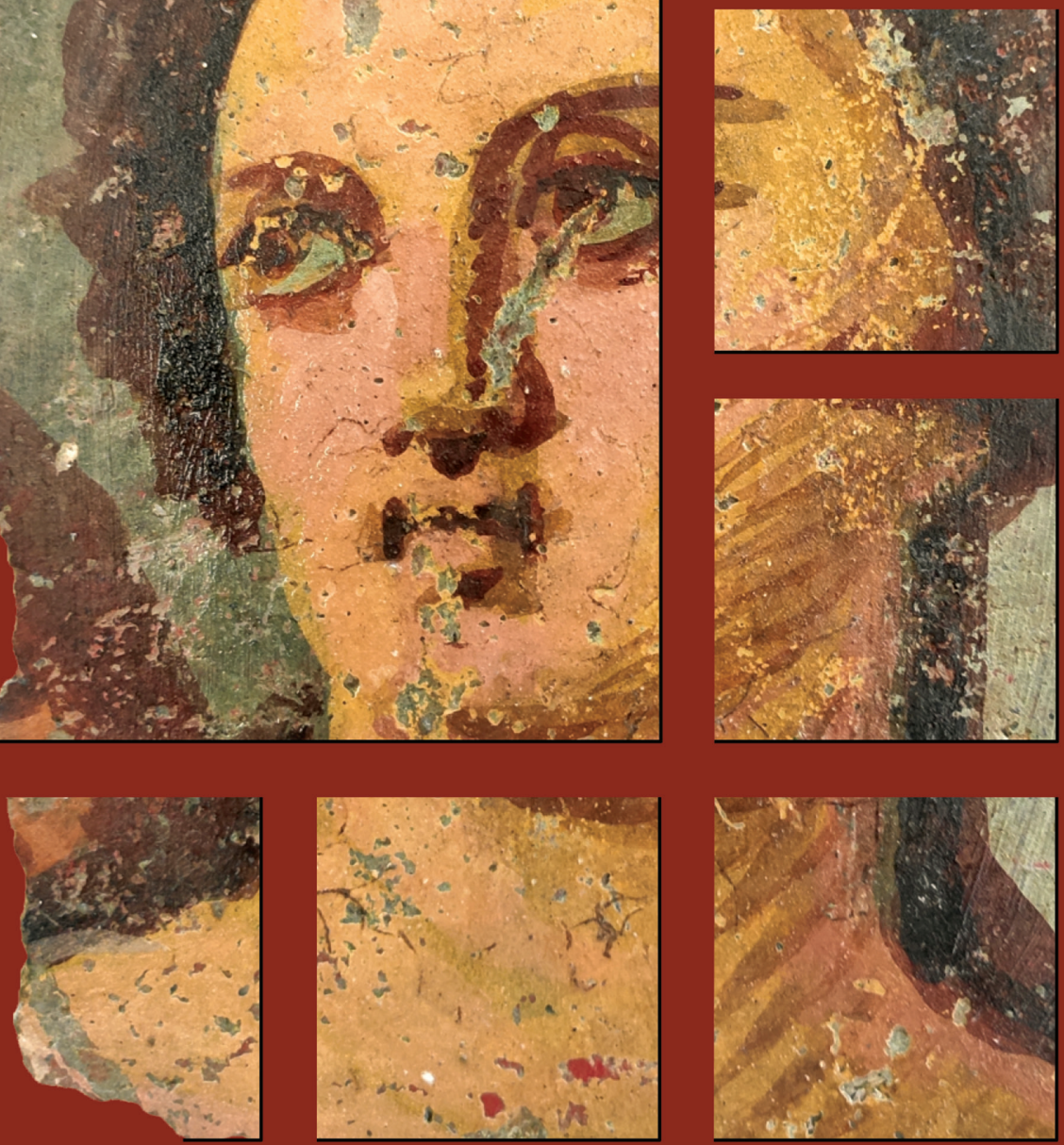

Serp 30 No. 8. 2020 


\section{Dissertationes Archaeologicae ex Instituto Archaeologico}

Universitatis de Rolando Eötvös nominatae Ser. 3. No. 8.

Budapest 2020 
Dissertationes Archaeologicae ex Instituto Archaeologico Universitatis de Rolando Eötvös nominatae Ser. 3. No. 8.

Editor-in-chief:

DÁvid Bartus

Editorial board:

LÁsZló BARTOSIEWICZ

LÁsZLÓ BORHY

ZOLTÁN CZAJLIK

IsTVÁN FELD

GÁBOR KALLA

PÁL RACZKY

MiKLÓS SZABÓ

Tivadar Vida

Technical editor:

Gábor VÁczi

Proofreading:

Szilvia BARTUS-SzÖLLŐsI

Zsófia KondÉ

Márton SZILÁGYI

Aviable online at http://ojs.elte.hu/dissarch

Contact: dissarch@btk.elte.hu

ISSN 2064-4574

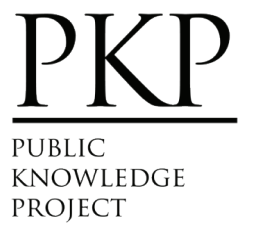

๑ ELTE Eötvös Loránd University, Institute of Archaeological Sciences

Layout and cover design: Gábor Váczi

Budapest 2020 


\section{CONTENTS}

\section{ARTICLES}

Maciej WAWRZCZAK - Zuzana KASENČÁKovÁ

Stará L'ubovña - Lesopark. Late Palaeolithic site and the problems associated with raw material mining

Attila PÉNTEK - Norbert FARAgó

Chipped stone assemblages from Schleswig-Holstein (North Germany) in the collection of the Institute of Archaeological Sciences - ELTE Eötvös Loránd University

Bence Soós 49

Middle Iron Age Cemetery from Alsónyék, Hungary

Tamás Szeniczey - Tamás Hajdu 107

Appendix - Results of the analysis of the Early Iron Age human remains unearthed at Alsónyék, Hungary

Lajos JuHÁsz - József Géza Kiss

Bound in bronze - a Roman bronze statuette of a barbarian prisoner

Csilla SÁRó

The fibula production of Brigetio: clay moulds

\section{Field Reports}

András Füzesi - Knut Rassmann - Eszter BÁnffy - Hajo Hoehler-Brockmann -

Gábor Kalla - Nóra Szabó - Márton SzIlágyi - Pál Raczky

Test excavation of the "pseudo-ditch" system of the Late Neolithic settlement complex at Öcsöd-Kováshalom on the Great Hungarian Plain

Gábor VÁczi - László RupNIK - Zoltán CZAJLIK - Gábor MEsterházy Bettina BitTner - Kristóf FÜlöP - Denisa M. LÖNHARdT - Nóra Szabó

The results of a non-destructive site exploration and a rescue excavation at the site of Pusztaszabolcs-Dohányos völgy északi part

Dávid BArtus - László Borhy - Szilvia JohÁczi - Emese SzÁmadó 181

Excavations in the legionary fortress of Brigetio in 2019 
Dávid BArtus - László Borhy - Emese SzÁmadó - Lajos Juhász - Bence Simon -

Ferenc Barna - Anita Benes - Szilvia Joháczi - Rita Olasz - Melinda Szabó

Excavations in Brigetio in 2020

\section{Thesis Abstracts}

Anett OszTÁs

The settlement history of Alsónyék-Bátaszék.

Complex analysis of its buildings in the context of the Lengyel culture

Csilla SzÁRAz

The region of the Zala and Mura Rivers (Zala County) in the Late Bronze Age.

Late Tumulus and Urnfield period

Ágnes KIRÁly

Human remains unearthed in settlement context from the Late Bronze Age -

Early Iron Age (Reinecke BD-HaB3) Northeastern Hungary

Gergely BóKA

Transformation of settlement history in the Körös Region in the period between the Late Bronze Age and the end of Iron Age

Gabriella G. DeLbó

Pottery production of the settlement complex of Brigetio

Adrienn Katalin BLAY

Die Beziehungen zwischen dem Karpatenbecken und dem Mediterraneum

von der II. Hälfte des 6. bis zum 8. Jahrhundert n. Chr. anhand Schmuckstücken

und Kleidungszubehör

Levente SAMU

293

Die mediterranen Kontakte des Karpatenbeckens in der Früh- und Mittel-

awarenzeit im Licht der Männerkleidung. Gürtelschnallen und Gürtelgarnituren

\section{REviEWS}

Gábor MESTERHÁZY

Czajlik, Z. - Črešnar, M. - Doneus, M. - Fera, M. - Hellmith Kramberger, A. Mele, M. (eds): Researching Archaelogical Landscapes Across Borders - Strategies,

Methods and Decisions for the 21th Century. Graz-Budapest, 2019. 


\title{
Human remains unearthed in settlement context from the Late Bronze Age - Early Iron Age (Reinecke BD-HaB3) Northeastern Hungary
}

\author{
Ágnes KirÁLY \\ Archaeological Intitute \\ Research Centre for the Humanities \\ agneskiraly87@gmail.com
}

\begin{abstract}
Abstract of PhD thesis submitted in 2020 to the Archaeology Doctoral Programme, Doctoral School of History, Eötvös Loránd University, Budapest under the supervision of Gábor V. Szabó.
\end{abstract}

\section{Research questions}

Over the course of the European Bronze Age, many kinds of funerary customs were present in Europe from simple inhumation to rich tumuli burials with stone chambers, requiring large investment of energy. Cremation rite became commonplace across the continent including the Carpathian Basin by the 1st millennium BC: cemeteries that consisted of smaller or larger groups of urn graves can be found within the territory of all Hungarian Late Bronze Age archaeological cultures (Urnfield culture in Transdanubia, Piliny and Kyjatice cultures in North Hungary and Gáva culture in Eastern Hungary) as well. In the last decade, however, more and more settlement features came to light from the given period that contained human remains (scattered bones, partial or complete skeletons).

The only published Transdanubian example of this phenomenon is from Gór-Kápolnadomb (Vas county), where a Late Bronze Age pit containing three, fairly robust male skeleton was discovered in the late ' 80 s by Gábor Ilon. In contrast to Transdanubia, we know approximately 140 features with human remains from 24 sites in the eastern and especially from the northeastern parts of Hungary by now. Human remains unearthed in settlement context (hereinafter: HRSC) are mostly present in the territory of the Gáva culture (Hajdú-Bihar, Jász-Nagykun-Szolnok and Szabolcs-Szatmár-Bereg counties) but some of them are known from the habitation area of the Piliny/Kyjatice cultures and the previous, Pre-Gáva period (Borsod-Abaúj-Zemplén and Heves counties) as well.

Regardless of sex, age and state of preservation, HRSC are usually found in storage or waste pits, wells and settlement ditches. Some of the corpses are intact, however, most of them are incomplete or highly disturbed. It is not uncommon to find single bones (mostly skulls, mandible fragments or long bones) comingled with household waste as well. Sites revealing multiple features with human remains and pits containing the leftovers of several individuals, even human and animal corpses together are quite frequent phenomena. Despite the constantly broadening database, the state of preservation and the context (location, accompanying artefacts, etc.) of the HRSC is so diverse that - apart from the fact that they all derive from settlement features - no logical relationship can be discerned between them at first glance. 


\section{Methods of investigation, levels of interpretation}

The reconstruction of the formation processes of HRSC is based on the main concepts of the so-called archaeothanatology (the archaeology of death), a widely used method for studying human cadaver taphonomy established by French archaeologists.

The investigation started at the smallest unit: with the study of the deceased itself. At this level, physical anthropological examination (sex and age determination, mapping injuries or diseases, etc.), stable isotope/DNA analysis and archaeological evaluation of body ornaments/ costume elements was carried out in order to gain data on personal identity, social status, life conditions and cause of death.

At the second level, the analysis of gestures took place, where archaeological traces possibly referring to the treatment of the body were analyzed. Body orientation, placing the dead, body ornaments and additional artefacts, state of human remains, representation of body parts, signs of peri- or post-mortem manipulations, traces of intentional or instinctive actions to the cadaver all equally contribute to the reconstruction of the HRSC placement scenario. The archeological feature itself was examined in order to determine whether it was created with the special purpose of placing human remains in it or an already existing sunken feature was chosen for the deposition. The position of the remains sometimes suggested that they were wrapped in something or that someone had accompanied the cadaver/bones into the grave in order to arrange the body parts carefully.

At the third level, data on the original function of the sunken features that contained human remains was evaluated. Beyond determining main characteristics of the features (morphology, dimensions, nature of

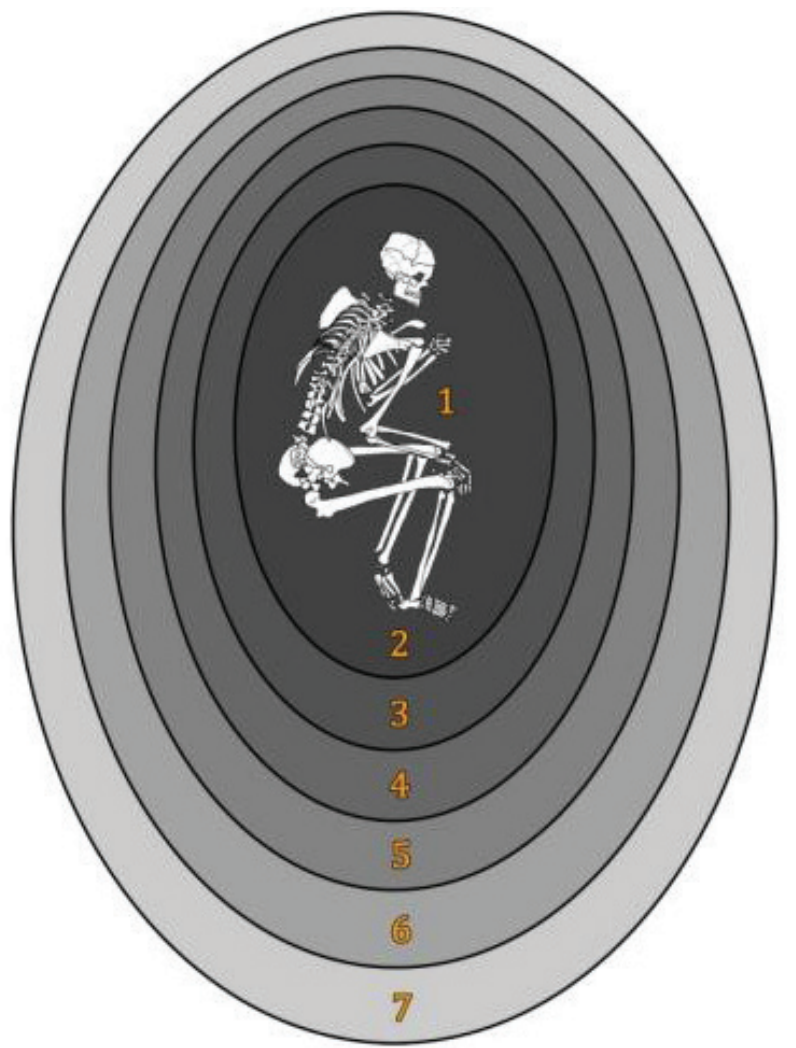

Fig. 1. Interpretation levels of human remains unearthed in settlement context (After BonNABEL 2010, 101. Fig. 2). Extended version by the author: $1-$ the deceased (le défunt), 2 - the gestures (les gestes), 3 - the structure (la structure), 4 - the site (le site), 5 - the region (la region), 6 - contemporaneous analogies; 7 - universal trends. the infill layers), the analysis focused on the reconstruction of the formation processes, time of feature abandonment (if there was) and acts prior to and following the placement of human remains (cleaning, building, filling, reopening of the pit, etc.).

The current condition of the find material and documentation proved to be insufficient for carrying out analyses at the 4th-6th levels (the location of the features within each site and their relationship to other features in the settlement; regional and intra-period trends). In the last chapter of my dissertation I have collected some important aspects for the study of universal trends. 


\section{Results}

- Gender and age distribution of human remains unearthed in settlement context (similarly to those found in cremation cemeteries) are very similar to a living population. This form of body disposal, therefore, cannot be associated with specific social groups/subcategories.

- The condition of the remains and the high percentage of post-mortem manipulation of the bodies implied that Late Bronze Age human cadavers were very often subjects to some kind of secondary (ritual?) action. The archaeological traces of these manipulations are frequently observed in various settlement contexts.

- Within this "special" group of finds, distinct sequences of events could be ascertained (e.g. the story of the "goat-head man" of Pácin-Alharaszt, ft. 487, the trophy-like skull from Ludas-Varjú-dűlő, ft. 1935 or the collective deposits of human remains at Pusztataskony-Ledence). In addition to such individual cases, certain attitudes and associations could be defined, e.g. the association of deer antlers to infants/juveniles or the association of young women and children in multiple human deposits.

- Even though the number of cases is small, we can assume a possible regularity and a probable significant (symbolic?) role of placing grinding stones associated to HRSCs.

- There seems to be a stronger and more definite association between HRSCs and some kind of burning activity around human remains (next to or within the sunken features). Through this, a double cognitive link between the deceased and the chtonic (storage pit, descent) as well as the spheric (cremation, smoke) realms. Furthermore, the interoperability between different manipulation attitudes/burial rites can be assumed through this habit.

- It is still unclear whether HRSCs can be interpreted as "real" burials. Furthermore, we still cannot determine if - as a part of the funerary cycle - they were related to "traditional" burials in cemeteries, and if so, how. We can only hope for more or less satisfactory results after a detailed reconstruction and comparative analysis of the formation processes of cemetery graves, as well as regional and intra-period studies of Late Bronze Age - Early Iron Age HRSC.

\section{The publications released in the topic of the dissertation}

KIRÁLY, Á. 2012: A biritual cemetery of the Gáva culture in the Middle Tisza Region and some further notes on the burial customs of the LBA-EIA in Eastern Hungary. In: MARTA, L. (ed.): The Gáva culture in the Tisa Plain and Transylvania - Die Gáva-Kultur in der Theißebene und Siebenbürgen. Symposium Satu Mare, 17-18 June/funi 2011. Studii sị Comunicări - Archeologie 28. Satu Mare, 109-132.

KirÁly, Á. - SebőK, K. - K. Zoffmann, Zs. - KovÁcs, G. 2013: Early Iron Age 'Mass Graves' in the Middle Tisza Region: Investigation and Interpretation. In: MülLER-ScheEssel, N. (Hrsg.): ,Irreguläre' Bestattungen in der Urgeschichte: Norm, Ritual, Strafe...? Akten der Internationalen Tagung in Frankfurt am Main vom 2. bis 4. Februar 2012. Kolloquien zur Vor- und Frühgeschichte 19. Bonn, 307-326.

KiRÁLy, Á. 2013: Újabb adatok az alföldi Gáva-kultúra temetkezéseinek problémájához: birituális temető Tiszabura-Nagy-Ganajos-háton. Tisicum - A Jász-Nagykun-Szolnok megyei múzeumok évkönyve 22, 31-64. 
KIRÁLy, Á. 2016: A terminológia halálától a halál terminológiájáig. Megjegyzések a temetkezés fogalmához és a temetkezési ciklus állomásainak nevezéktanához. Tisicum - A fász-Nagykun-Szolnok megyei múzeumok évkönyve 25, 297-302.

KIRÁLY, Á. 2018: Vándorló testrészek - „élő” halottak: különleges halottkezelési szokások a késő bronzkori Kárpát-medencében. Határtalan régészet 2018. június, 30-33.

\section{References}

BonnABEL, L. 2010: Dépôt de corps humains en structures réutilisées (ou détournées?) durant la Protohistoire en Champagne-Ardenne : approche comparative avec les sépultures et éléments d'interprétation. In: BARAY, L.-BOulestin, B. (dir.): Morts anormaux et sépultures bizarres. Les dépôts humains en fosses circulaires et en silos du Néolithique à l'âge du Fer. Actes de la IIe table ronde interdisciplinaire «Morts anormaux et sépultures bizarres: questions d'interprétation en archéologie funéraire» 29 mars 1er avril 2006, Sens. Dijon, 99-112. 